\title{
An art of hunger: Gender and the politics of food distribution in Zakes Mda's South Africa
}

The Journal of Commonwealth Literature

(C) The Author(s) 2016

Reprints and permissions: sagepub.co.uk/journalsPermissions.nav DOI: $10.1177 / 0021989416658783$ jcl.sagepub.com $\odot$ SAGE

\author{
Katherine Hallemeier \\ Oklahoma State University, USA
}

\begin{abstract}
This article examines the centrality of hunger and food in Zakes Mda's Ways of Dying, The Heart of Redness, and The Whale Caller. While Mda's work has been the subject of incisive readings of the politics of development in contemporary South Africa, attention to his treatment of hunger, specifically, helps to clarify the centrality of gender to Mda's critical re-envisioning of development policies pursued by late and postapartheid governments.
\end{abstract}

\section{Keywords}

Zakes Mda, South African literature, hunger, development, African literature

Three of Zakes Mda's late apartheid and postapartheid novels describe men with distinctive favourite meals. In Ways of Dying (1991/1995: 14), Toloki's peculiar favourite food, "a delicacy of Swiss cake relished with green onions", is memorable enough that it is alluded to in the title of the jazz opera based on Mda's novel, Love and Green Onions (Weale and McLea, 2001). Concomitantly, The Heart of Redness (2000) begins with a description of Bhonco's committed preference for canned beef, while The Whale Caller (2005) foregrounds the titular protagonist's steady diet of macaroni and cheese. ${ }^{1}$ In accordance with his magical realist style, Mda makes it clear that these accounts of food, though fantastical, are yet plausible, especially insofar as they are indicative of each character's desire to establish himself as someone of social worth. Toloki and Bhonco both describe their favourite meals in terms of "luxury" (Mda, 1991/1995: 162; 2000:

\section{Corresponding author:}

Katherine Hallemeier, Assistant Professor, Department of English, Oklahoma State University, 205 Morrill Hall, Stillwater, OK 74078, USA.

Email: katherine.hallemeier@okstate.edu 
10), while the Whale Caller characterizes his as "decent" (Mda, 2005: 93). Each establishes his identity as a man of some stature through conspicuous consumption, whether of unusual, processed, or readily available meals.

Food, consequently, is one way to centre an analysis of Mda's satire of the entrenched inequalities that comprise South African society. Mda's novels denounce the politically engineered poverty that renders Swiss cake and canned beef "luxuries", or a monotonous diet of mac and cheese "decent". Taken together, the fictions offer a devastating fictionalized history of hunger and food insecurity across South Africa's colonial, apartheid, and postapartheid eras, even as they lampoon development schemes that have identified purported solutions for remedying wildly unequal access to sustenance. More specifically, the fictions suggest that Toloki's entrepreneurism, Bhonco's support for tourism, and the Whale Caller's access to state grants provide inadequate bases for addressing the systemic inequalities indexed by the characters' preferred foods. Broadly speaking, Mda's work thus draws attention to the paradox whereby the South African Constitution guarantees the right to access sufficient food at the same time as the South African government estimates that food insecurity continues to significantly structure daily life for almost 14 million people (Department of Agriculture, Forestry and Fisheries, 2014: 24, 30). The declaration of a right to food, the fictions underline, has not proved adequate to ensuring this right.

What is more, the novels suggest that discourses of rights and development have occluded claims to material and social equality that exceed the logic of necessity upon which such discourses are premised. Even as Mda's fictions ironize their protagonists' assertions of what constitutes a luxurious or decent meal, they do not satirize the fact that claims to luxury and decency express a desire for the more equitable distribution of both material resources and social influence. Instead, as this essay will highlight, the fictions explore the gendered ways such desire is negotiated within contemporary discourses of development. In so doing, Mda's novels challenge not only extant notions of rights within those discourses, but also of responsibilities. As I will demonstrate through sequential yet interrelated close readings, in Ways of Dying, The Heart of Redness, and The Whale Caller, food preferences not only mark how men assert claims to that which is pleasurable and respectable, but also how they distinguish themselves from the women around them. The aspirations that their distinctive tastes point toward implicitly depend upon the disproportionate, often uncompensated labour of women living in racialized poverty, who are assumed to be responsible for the daily physical and spiritual nourishment of others. Mda's fictions, however, stage an alternative vision of development, whereby the responsibility for the daily, necessary work of nourishment is more equitably shared. Against a South African politics of food distribution delimited by a restrictive notion of "right" and dependent on allocating unequal responsibilities to women, Mda's work imagines a politics of abundance, wherein the responsibility to contribute to a communal feast is shared by all.

\section{Of Swiss cake and pap in Ways of Dying}

In Ways of Dying, Toloki perceives his taste for the "unusual combination" of Swiss cake and green onions as integral to his famous identity as a Professional Mourner: "although [the meal] is of his own composition, it gives him an aura of austerity that he associates 
with monks of eastern religions that he has heard sailors talk about" (Mda, 1991/1995: 15). ${ }^{2}$ For Toloki, cake and onion is a way of appearing "austere and ascetic" (114); it is a means by which he can add "glamour" to his poverty and present his mourning as an "essential service" (15). Toloki, in brief, eats Swiss cake and green onions because he believes it will be good for his personal brand. Mda's novel satirizes such glorification of individual tastes, as well as a closely associated ideology of entrepreneurialism that depends upon similarly glorifying individual capacities. It also, however, suggests that a more just communal life necessarily requires promoting the expectations of full equality that Toloki relishes through his sensual enjoyment of cake.

To be sure, the ironies of Toloki's "professional" gustatory practices are manifold. Toloki aspires to appear austere in a context where, evocative as the novel is of late apartheid South Africa, conditions of austerity are oppressive and enforced. Likewise, he presents his mourning as exceptional in a context where death and mourning seem inescapable. As Toloki repurposes poverty and death as the basis for entrepreneurial endeavour, Mda's novel highlights the potential absurdity of Toloki's propensity for indulging eccentric tastes and seeking payment for mourning during a time of widespread scarcity and grief. In so doing, the novel draws attention to its own potential absurdity: it is, after all, a distinctively stylized work of mourning initially marketed for profit during South Africa's interregnum. Mda invites readers to consider how Toloki's qualifications for being a professional mourner may be comparable to Mda's own. Consequently, while Ways of Dying, as Goyal (2011: 165-6) has shown, suggests how "the contemporary artist can turn to the painful past to find resources for living in the present and imagining the future", it also flags the possible ethical and political limitations of creative aesthetic practice.

Besides raising questions about the role of art in the context of social crisis, however, Toloki's cultivation of his professional image also raises questions about a, by now, robust discourse of development that centres on the promises of entrepreneurial endeavour. Toloki, after all, conceives of his work as not only producing a desired service but also as containing the potential for growth, namely of an "austere and ascetic votary of my own order of Professional Mourners" (114). As such, his self-presentation resonates with what James Ferguson (2015: 98-9) characterizes as a neoliberal, "optimistic account" of the "so-called informal economy" that perceives the "informal improvisatory labor" of the "urban poor" as having "a vast potential for "creating jobs" . As Ferguson (2015: 92, 99) argues, while a worldview that maintains that "every poor person scrambling for a livelihood can be treated as one or another sort of productive entrepreneur or firm" aims to "defend the moral and economic virtue of the urban poor", it risks eliding the precariousness and adversity of the conditions under which such work is undertaken. As Mda makes clear, Toloki's "profession" is not one that affords him a regular wage. The growth of his order would indicate the continued violence and destruction wrought by the apartheid state, even as the fact of his entrepreneurial efforts, as Makhulu (2012: 792) has suggested, "alludes to the expanding service economy (formal and informal) and the emergence of modes of precarious and contingent work" in South Africa's transition period. Given these considerations, Toloki's work as a mourner may be better understood as an example of what Ferguson (2015: 94) describes as "survivalist improvisation" that splinters, rather than grows, markets and that distributes, rather than produces, resources. 
Even as Mda parodies the idea that Toloki's work holds the potential to significantly affect systemic unemployment and impoverishment, his novel takes seriously Toloki's desire for a professional identity and the social recognition and economic security that attends it. Toloki's delight in cake and green onions may be risible as a means to glamourize or even ameliorate conditions of extreme austerity, but it is not risible in and of itself. On the contrary, by claiming social worth in part through his cultivation of distinctive tastes, Toloki arguably asserts a vision of material and social dues that exceeds the logic of market potential implicit to notions of entrepreneur-based development. When Toloki appears at funerals and requires payment for his mourning, he, like a windshield washer or a car guard, makes what Ferguson (2015: 48) characterizes as a "direct distributive demand" that "articulates a need or a desire without grounding it in a recognizable framework of justification". More specifically, he participates in a politics of distribution that marks a shift from a discourse of rights to a discourse of what is rightful (Ferguson, 2015: 50). Toloki, that is, does not claim a right to either cake relished with onions or to the resources of funeral attendees, but he does claim that it is rightful that he have access to both. Toloki thus participates in what Ferguson (2015: 178) calls a "politics of the rightful share", which, by rendering the distribution of resources as rightful, as opposed to commercial, reciprocal, or charitable, revalues relations of dependency so as to do away with the "stigma, humiliation, shame, [and] the lack of self-worth associated with getting "something for nothing", that has regularly accompanied the institution of capitalism. Insofar as such stigma has often especially affected able-bodied men whose sense of masculinity and personhood has been closely entwined with earning a wage, the politics of the rightful share that Toloki promotes also provides a basis for "male personhood" that accommodates the explicit acknowledgement of dependency (Ferguson, 2015: 46).

The narrative arc of Ways of Dying moves beyond exemplifying Ferguson's important work on gender, dependency, and distribution, however, by suggesting the value of a politics of distribution in which a masculine subject not only directly claims material goods but also responds to the direct claims of others. While Ways of Dying upholds the social and economic value of Toloki's profession, it simultaneously challenges a gendered tendency toward delimiting relationships of dependency that Toloki's pleasure in cake and onions, for example, partly represents. Toloki's first meal with another person in the narrative's present sees him enjoying his special meal alone, while his companion, Noria, eats only the cakes he has purchased for her. Noria, who is trying to rebuild her life in an informal settlement after the murder of her son, in part by helping to care for orphaned children, privately reflects that "buying cakes is a waste of money" and that "Toloki should have brought something more practical - like mealie-meal, sugar, tea, dripping, or paraffin" (114). Though she does not voice her disapproval, her valuing of practicality born of her sense of responsibility to the community's children nonetheless has an effect on Toloki, even as his seeming eccentricities affect her in turn. As Noria and Toloki teach each other "other ways of living", both Toloki's and Noria's attitude toward the distinctive meal changes (115). Toloki finds himself enjoying the pap that Noria prepares for him (151). Noria, for her part, finally "tries the Swiss roll with green onion and falls in love with the combination" (211). The changing tastes of the characters suggest a reconstitution of the social role of the male 
"entrepreneur", who would locate himself and his work within a venerable tradition of labour and thereby claim particular entitlements.

This is to say that by the end of the novel, Toloki's claims to these entitlements cannot be understood as distinctively his: Noria, too, clearly craves those goods that fall outside discourses of necessity and rights but that nonetheless may be claimed as rightfully hers. At the same time, Toloki's sense of responsibility to others expands: his "essential service" of mourning comes to be complemented by his work with the abandoned children, with whom he shares cakes "like sacramental wafers" (211). Toloki's view of the occupation of votary transmutes from that which deserves veneration and remuneration to that which serves others. The entrepreneur's hunger for recognition becomes reformed as the recognition of his responsibility to respond to others' hunger, both for sufficient and pleasurable food and for partaking in the luxury and pleasure of creative life. The promising politics of distribution suggested by Mda at the end of Ways of Dying is one in which the masculine subject is not only willing to inhabit a position of explicit dependency by claiming a rightful share of others' wealth but also to take responsibility for responding to those range of claims that have erstwhile been understood as the responsibility of women.

\section{Of canned beef and imbhatyisa in The Heart of Redness}

The project of considering who makes claims to a rightful share of food and who has been accorded responsibility for its daily preparation and provision to others has proven a recurrent theme in Mda's fiction. Incisive critics of The Heart of Redness have demonstrated that the novel offers insight into how the living history of colonial trauma in postcolonial and postapartheid South Africa affects the construction of communal and national identities, as well as conceptions of ecological responsibility. ${ }^{3}$ Less commented on is how the novel, set both in the mid-nineteenth century and in 1998, offers a comparative literary history of food and hunger in the Eastern Cape. Attentiveness to this history, however, throws into relief the limitations of the protagonist Camagu's grassroots, tourism-based model of development that has been celebrated as the novel's primary political intervention. Like Ways of Dying, The Heart of Redness challenges an authoritative discourse of South African development, albeit with particular attention to the postapartheid state's support for the developmental aims of privatized organizations, both corporate and nongovernmental. Tracing the material and social claims implicit in gustatory desires in The Heart of Redness once again serves to clarify Mda's gender-based critiques of those aims.

The theme of hunger and its political causes and consequences is one of many that unites the two narrative strands of The Heart of Redness. Indeed, starvation is horrifyingly explicit in the novel's account of kwaXhosa in the mid-nineteenth century. Mda, who somewhat controversially has based his account of the historical events of 1856-57 on J. B. Peires's The Dead Will Arise (1989), describes the suffering that follows from these events. ${ }^{4}$ In brief, after Dutch-imported lung sickness spreads among the cattle of the amaXhosa people, the prophet Nongqawuse calls for the slaughter of cattle and the cessation of cultivation, foreseeing that then the "the whole community of the dead" will arise with new livestock and animals (Mda, 2000: 54-5). ${ }^{5}$ Conflict develops between the 
Believers of Nongqawuse and the Unbelievers. The ensuing violence and mass starvation are exploited by the British to consolidate their rule over kwaXhosa and to pursue genocidal policies (Mda, 2000: 206). ${ }^{6}$

In the late twentieth-century narrative, the legacy of these events is in evidence, as the people who live in the village of Qolorha-by-Sea alternately blame Believers and Unbelievers for "the sufferings of the Middle Generations" that were endured during the years of colonial rule and apartheid, the effects of which continue to shape daily life (91). Although these "sufferings" stand as a traumatic lacuna in Mda's novel, they allude to colonial and apartheid policies that resulted in ongoing hunger and impoverishment. In the Eastern Cape, the Ciskei and Transkei "homelands" were "the poorest rural areas throughout apartheid years" (Kepe and Tessaro, 2014: 269). Apartheid schemes such as the Transkei Agricultural Corporation and Farmer Support Centers aimed to develop agriculture "as a way of trying to show that the reserve (Bantustan) system could work", but they "did not make a significant dent in fighting poverty" (Kepe and Tessaro, 2014: 270).

The question of what to do next in the postapartheid foodscape of the Eastern Cape, where it is currently estimated that 80 per cent of households regularly experience hunger, establishes a central conflict in the contemporary narrative of The Heart of Redness (Kepe and Tessaro, 2014: 267). There is, most immediately, the corporate solution. Developers, supported by the national government, have proposed to a build a casino gambling complex, promising that it will bring new jobs and income to the community. Bhonco, the leader of the modern-day Unbelievers, sees the scheme as an opportunity for "progress" and "modernization" (66-7). His daughter, Xoliswa Ximiya, concurs: "This is a lifetime opportunity for Qolorha to be like some of the holiday resorts in America. To have big stars like Eddie Murphy and Dolly Parton come here for holiday" (67). Both father and daughter associate social and economic status with those objects and projects linked with American capital. Hence, Bhonco, to his wife NoPetticoat's dismay, goes into debt to purchase his coveted canned beef: it represents, to him, a sign of modernity (10).

Mda's lambasting of the association of corporate capital with "progress" is unstinting. The "casino and the water-sports paradise" emerge as self-evidently neocolonialist, promising both social and ecological destruction (71). The national government has rubber-stamped a white-dominated corporate venture that, far from bringing prosperity to Qolorha, will in fact threaten that prosperity, particularly because villagers will lose access to the sea when it is claimed as private property for rich tourists. This access is important because the women of Qolora harvest imbhaza (mussels) and imbhatyisa (oysters), both to sell to the local Blue Flamingo Hotel for income and to feed their families (102). Served with "maize porridge or samp", the dishes are "very tasty and healthy food" (102). Yet, Bhonco's association of luxury with the US renders him indifferent to the local seafood that is often marketed in the US as a luxury. The irony is multiplied insofar as Bhonco's preferred project would render a daily food source as an unaffordable "luxury" item. Mda thus skewers postapartheid development policies that have privileged formal markets and public-private collaboration, while often marginalizing informal markets and safety nets that can radically affect food availability and accessibility (Battersby, 2012: 155). ${ }^{7}$ He critiques a government that, as Jacobs (2011: 649) demonstrates, has been "ineffective in curbing powerful corporations from dominating and manipulating food production, markets, and distribution systems for private gain". 
While Mda's novel makes short work of Bhonco's desire for corporate-driven development, it yet takes seriously the claim to greater social and material equality that underpins that desire. When Bhonco pleads with the shop owner John Dalton to sell him tinned beef on credit, he regards his access to such credit as rightful, and the novel as a whole does not challenge this claim. Bhonco insists that, given his past labour of "working for this country", he deserves an old-age pension and the status and degree of economic security it affords (10). While Mda's novel may satirize Bhonco's means to achieving this end, it upholds the end itself. After all, Bhonco's logic of a rightful share is echoed by the protagonist who takes the lead in propounding an alternative to the gambling complex. Camagu, a South African, American-educated "international expert" in development and communication (29), argues that the casino will come at "the expense of the freedom to enjoy the sea and its bountiful harvests" (103). The alternative to national policy that Camagu supports consequently aims to develop a productive business that will ensure the continuance of what he understands to be the community's rightful claim to the sea and its resources.

Specifically, Camagu organizes a "cooperative society" in which he helps women to "sell their sea-harvest to hotels and restaurants in East London" and beyond (178). In lieu of the resort complex, he proposes applying the cooperative model to the establishment of an amaXhosa owned "holiday place", which could attract "backpackers" and tourists interested in the "historical significance" of Qolorha-by-Sea (240). The scheme is one that has been lauded by readers, who plausibly tend to interpret Camagu as an authorial place-marker for Mda, who is likewise an intellectual who lived in exile in the US during apartheid. Oliveira Gonçalves Pires (2013: 143), for example, argues that Camagu's project takes advantage of "globalized processes already under way in order to benefit the local community". Mike Kissack and Michael Titlestad (2009: 163) argue that Camagu permits the people of Qolorha-by-Sea "some independence in the construction of a new identity in a time of social transformation". Camagu's holiday place is in many respects a model of the modern enlightened development agency, such as is upheld by advocates of a social justice model of food security policy: it is ostensibly grassroots and sustainable, and it claims to empower women living in poverty.

There are signs in the novel, however, that Camagu's scheme may also be read as the plausible object of significant critique, especially in light of Toloki's initial ineffectual self-centredness in Ways of Dying. For Camagu, notably, regards the cooperative society and holiday place as evidence of his own brilliance and ingenuity, on the one hand, and of the decrepitude of the political regime he excoriates, on the other. That this selfcentredness is attended by a gendered sense of responsibilities is suggested in the final passage of the novel that is focalized through Camagu's consciousness. Having just come from visiting the hospital bed of his rival John Dalton (who has been grievously injured by his rival, Bhonco), Camagu congratulates himself that he has "won the day" against government and corporate interests: "The whole country is ruled by greed. Everyone wants to have his or her snout in the trough" (277). Camagu implicitly upholds himself as the exception to the rule of greed, and the dehumanizing connotation of "snout" amplifies the disdain he feels for those in power. Ironically, however, Camagu's hostility toward the national regime is based on the same competitive individualism that he attributes to and detests in his (consistently masculinized) rivals. Camagu sees himself as an absolute and 
autonomous opponent of the government, despite the fact that the cooperative depends upon his relative social and economic power, just as those whom he scorns rely on that of government officials. As Dalton's hospitalization signals, in one instance among many in the novel, a usual conclusion to such rivalry is ongoing violence.

Yet, the novel's project is not simply one of critique. Through its account and adaptation of the double-voiced singing practised by amaXhosa women, it gestures towards yet another model of development, this one more radical than Camagu's, in part because it is premised not on visions of autonomous production but on acknowledging and renegotiating a gendered politics of dependency. Here we come to the figure of Qukezwa, whose double-voiced singing repeats the synesthesia that marks creativity in Mda. (Toloki does not just taste onions and cake; he feels that "the food is singing in his mouth"; Mda, 1991/1995: 15.) As Qukezwa sings, she sings in colour:

Qukezwa sings in such beautiful colors. Soft colors like the ochre of yellow gullies. Reassuring colors of the earth. Red. Hot colors like blazing fire. Deep blue. Deep green. Colors of the valleys and the ocean. Cool colors like the rain of summer sliding down a pair of naked bodies.

She sings in soft pastel colors, this Qukezwa. In crude and glaring colors. And in bright glossy colors. In subdued colors of the newly turned fields. (193)

The multiplicity expressed in Qukezwa's song exceeds the singularity of her own voice; her art evokes her personal political views, but only to a degree. The reds and ochre recall the isiXhosa costume, isikhakha, and a particular vision of isiXhosa culture with which Qukezwa aligns herself (55). Yet, the singing is not necessarily limited to Qukezwa's personal commitment to her vision of an autochthonous heritage. Qukezwa, somewhat unexpectedly, also sings in "crude and glaring colors" that call to mind nothing more particularly than the gambling complex that she so vehemently opposes. Her art, in this respect, suggests a unity between her cause and the proponents of the gambling complex that is otherwise unrecognized. It sutures, rather than opposes; much as, in Mda's telling, the words of Nongqawuse and the later prophet Nonkosi were meant to suture: "it seemed that there was competition between the two prophets. In reality the competition was between their followers. The prophets spoke with one voice and did not see each other as rivals. All they wanted was to save the amaXhosa nation" (158-9). Qukezwa's singing, however, also moves beyond her professed commitment to the amaXhosa nation. In its many hues, it ineluctably recalls celebrations of postapartheid South Africa as a "rainbow nation". Unlike those easily critiqued celebrations, it also registers deep difference and disorder. Its form, in short, is prismatic, rather than neatly striped, a description that also applies to Mda's novel, which illuminates the differences and intersections that comprise amaXhosa, South African, and global communities. In Ways of Dying, Mda breaks down a tradition of the venerable masculine artist. In The Heart of Redness, he positions his artistry within a feminized tradition of multi-voiced singing. ${ }^{8}$

The political promise of this relation, which acknowledges dependency on women's creative labour, is gestured toward in the novel's final paragraph. The twentieth-century Qukezwa, who is here ambiguously merged with the Qukezwa of the nineteenth century, attempts to coax her son, Heitsi, into the sea, even as she "swallows a mouthful of fresh oysters": 
Oh, this Heitsi! He is afraid of the sea. How will he survive without the sea? How will he carry out the business of saving his people? Qukezwa grabs him by his hand and drags him into the water. Wild waves come and cover them for awhile, then rush back again. Qukezwa laughs excitedly. Heitsi screams even louder, pulling away from her grip, "No mama! No! This boy does not belong in the sea! This boy belongs in the man village!" (277)

Heitsi must learn to "harvest the sea", Qukezwa believes, so that he "will not go hungry", and, by extension, so that he will be able to "carry out the business of saving his people" (275-7). This final vision for communal salvation is one that notably does not depend upon vanquishing an enemy (be they government and corporate bureaucrats or "foreign" elements). Rather, it hinges upon a willingness to acknowledge dependency on women's labour, a commitment that Heitsi resists making. Heitsi's cries firmly assert his gendered difference from his mother: he twice declares himself to be "this boy", in order, presumably, to bolster his claim that his place is in the "man village". To leave the sea and belong to the man village is, in the symbolic economy of the novel, to abandon the perception of dependency and insist instead on the primacy and truth of political rivalries articulated by powerful men who imagine themselves as autonomous subjects.

Heitsi's resistance to take part in the sea harvest foregrounds anew the limits of Camagu's development projects. It draws attention to the fact that, for all that Camagu and his collaborators have achieved, the cooperative and holiday place still depend upon women's labour and management, while Camagu functions as its recognized leader. As in many market-driven development models, from cash transfers to targeted microloans, power significantly remains with the educated development professional. When Camagu addresses John Dalton in hospital, he argues that "we must all work together" (277). The claim at once elides and signals a gendered opposition in what is meant by "work together". Dalton is needed, says Camagu, for his "business expertise", just as Camagu has been needed for his expertise in development and communication. In practice, the arrangement translates into an asymmetry that Toloki observes during his time with Noria: "the women are never still", while men "dispense wide-ranging philosophies on how things should be" (175). In the cases of Camagu and John Dalton alike, the men's work keeps apart from that of the women they "work with", who harvest food, produce goods for sale, and see to the day-to-day functioning of the businesses.

By forcing Heitsi into the sea, Qukezwa works for a community in which acknowledging gender parity in labour produces new possibilities for negotiating the extractive and exploitative structure of the (inter)national economy. Camagu's holiday place remains, like the proposed gambling complex, dependent upon the patronage of wealthy American tourists, who benefit from a system that ensures their travel, lodging, and food costs will be relatively affordable. The future that Qukezwa wishes to ensure for her son, in contrast, is one in which she is not solely responsible for providing him with daily sustenance, and he is better prepared for accessing and using the resources available to him for the benefit of those with whom he lives, rather than for the benefit of a global elite. The political economy that Mda's novel looks forward to hinges on a willingness to listen to a feminized voice that, in order to prevent starvation, insists that men labour with — and acknowledge their dependence on — women. 


\section{Of macaroni and kabeljou in The Whale Caller}

In The Heart of Redness, the sea and its creatures represent hope for a more equitable order, in which the sea harvest is an enduring source of sustenance for those who have been dispossessed of land and denied ownership entitlements. The Whale Caller, published only five years after The Heart of Redness, sustains Mda's concern with intersections between ecological stewardship and economic development. In this later work, however, the sea and its luxuries are represented more pessimistically: access to the sea's resources has been circumscribed by regulations that privilege and formalize commercialism at the cost of the livelihoods of people who have already been marginalized. Qukezwa's hope for better cultivating resources for equitable use has given way to legislation that overwhelmingly favours the economically powerful. What is more, The Whale Caller draws attention to the severe, gendered limitations of the state's efforts to counter this inequality through the distribution of the kinds of pensions and grants that Bhonco, for example, so desires. Mda's novel thus registers increasing despair that an unjust status quo can be effectively countered. Unlike in Mda's earlier work, The Whale Caller declines to represent the satiation of hunger that at once encompasses and exceeds claims of necessity. As a result, the requirement that South Africa's gendered politics of distribution be re-envisioned to address the radically unequal distribution of material and social capital appears all the more urgent.

In broad strokes, the structure of The Whale Caller recalls and revises Ways of Dying so as to bring questions of hunger and distribution to a crisis. Like Toloki, the titular Whale Caller has a curious palate to match a curious occupation: he eats macaroni and cheese for almost every meal, and he specializes in playing a kelp horn that allows him to communicate with southern right whales, and especially with his favourite whale, Sharisa. Unlike Toloki's favourite meal, however, the Whale Caller's diet is not designed to produce a defiant aura of austerity: it is rather a sign of the protagonist's acceptance of austerity, which is at once enabled and circumscribed by the expansive programme of social grants implemented after apartheid (Ferguson, 2015: 9). The Whale Caller prefers macaroni and cheese because "old-age pension money can only go so far", plus "it's as decent a meal as you can get" (Mda, 2005: 93). ${ }^{9}$ Resigned to his marginal social and dependent economic status, the Whale Caller is committed to a life of "decency" that Mda ironizes insofar as it is characterized by both the Whale Caller's withdrawal from human society and the repression of his desires for all but minimal needs. The politics of distribution in postapartheid South Africa is one in which social grants have played "an absolutely vital role in sustaining poor households and communities and in preventing the worst sorts of destitution" (Ferguson, 2015: 8), but Mda's novel suggests that the resultant "decent" life may be drained of much life.

This point is emphasized through Mda's representation of the Whale Caller's eventual companion and foil, Saluni. Because South African social grant programmes exclude younger women who themselves have no legal dependants - as well as younger men like Toloki, who have mistakenly continued to be imagined to be potential wage earners, despite the fact that "conditions approaching full employment are simply not on the horizon in countries like South Africa" (Ferguson, 2015: 201) — Saluni is required to improvise survival strategies. Her red hair and distinctive costumes recall Toloki's preferred 
costume of a cape and suit and signal her need to be recognized as a distinctive individual, as well as her refusal to limit her claims of others to that which fits into discourses of rights and necessity. Like Toloki, she consciously and volubly craves recognition of her social worth. She both dreams of a singing career that will bring her to Hollywood and continually prods the Whale Caller to expand his diet and engage in "civilized living", complete with formal mealtimes and plates (226). The hunger for a rightful share, Mda insists, is not limited to those men (including, as Ferguson notes, Julius Malema) who have been prominent in articulating their "aspiration to ownership" on the national stage (Ferguson, 2015: 169).

As in Ways of Dying, The Whale Caller depicts a cisgendered, heterosexual union to suggest the possibility of finding a happy synthesis between extremes of claims to bare necessity and declarations of entrepreneurial autonomy. As the Whale Caller and Saluni enter into a relationship, each person opens up new possibilities for living for the other. Like Noria and Toloki, who paste magazine pictures to the walls of Noria's shack so they can imagine its many furnished rooms and garden, the two share moments of imaginative experience that point toward a desirable future. After eating their macaroni and cheese, they go "window shopping' at the supermarket" (91). The activity "entails strolling along the aisles, stopping at the shelves displaying food they like, and then eating it with their eyes" (91). The activity is part of their courtship, and, as in their courtship, it is a way in which the characters find their desires are pleasurably affirmed and validated, even as they care for each other. Even the ascetic Whale Caller is able to revalue the shopping trips not (or not only) as participating in a ravenous consumerist culture but also as implying a rightful claim to mutual society grounded in greater material equality. Yet, the ritual affirmation of the characters' shared rightful claims does not result, as in Ways of Dying, in the funneling of these claims toward a recognition of broader dependency and responsibility and effective service to the broader community. The polarities in The Whale Caller, between social life and social death, between invisibility and spectacle, and between having too much food and having not enough, prove too extreme for the characters to cultivate even precarious forms of sustaining community.

This extremity is directly related to the novel's setting. As in The Heart of Redness, this later fiction engages directly with the investment of the state in South Africa's tourism industry. Whereas The Heart of Redness imagines alternatives to extant development policies, The Whale Caller considers the devastation wrought in the wake of such policies. Set in the Western Cape rather than the Eastern, the Whale Caller and Saluni navigate life in Hermanus, where millionaires and tourists flock to go whale watching and to engage "in the ritual of gorging quantities of seafood and gallons of wine" (107). In the prevailing culture of Hermanus, creative endeavour quickly takes the form of a spectacle for the rich and is encouraged or discouraged based on the pleasure it brings them. "Spectacular street performers" entertain tourists during the annual Kalfiefees (20). Yet, the young singer Lunga Tubu, who must sing "for his supper and his fees at Lukhanyo Primary School", is regularly prevented from performing outside of the restaurant where he "nags the delicate souls" who are enjoying their dinner (110-11). His plight is also the Whale Caller's and Saluni's, when they decide they will go for an "evening out", in which they "dine" at restaurants like they "shop" at the grocery store (144). A restaurant host welcomes their covetous stares, until it becomes clear they do not intend to enter the 
restaurant and pay for a meal: "You make my customers nervous watching them like that. Please go and be spectators somewhere else" (146). Enjoyment is enforced as the purview of the wealthy, who may exploit or suppress the creativity of people living in poverty as suits their pleasure and profit: claims to what is rightful are easily ignored. The Whale Caller's intuition that there is something "obscene" in the restaurant patrons' spectacular consumption of food, however, goes unheeded (148).

The efforts to maintain Hermanus as "a sanctified playground of the rich" finally overwhelm the main characters' efforts to satiate their physical hunger, as well as their intimately related craving for creative association (110). With regard to the former, postapartheid policies have ensured that the sea is no longer a source of sustenance for those who live in the village and are not wealthy. During the years of his wanderings, the Whale Caller was able to survive on fish, "some of which he bartered to non-fishing folks for grain and other necessities" (13). After returning to Hermanus, he considers "line fishing for a living" but "discards the idea", both because it would take away from his time with the whales and because he would have to obtain a fishing permit that "would only allow him ten fish a day" (209). Mda emphasizes here what numerous studies have shown, namely, that postapartheid fishing regulations have done little to secure and protect the fishing rights of small-scale fisheries and fishers (Isaacs, 2011; Mather, 2007; Salo, 2007). Efforts to ensure economic competitiveness and environmental sustainability (to further ensure that competitiveness) have come at the cost of social justice (Mather, 2007: 221). The point is emphasized again after the Whale Caller does catch a large kabeljou, which proves to be most valuable, not at home on the table or sold at market, but as yet another tourist attraction. Saluni discovers that unlucky fishers will pay to be photographed with the fish, at least until it rots: "There are no quotas when you rent out your fish" (219). This ingenious negotiation of the tourist industry emphasizes how thoroughly the economy has been structured to benefit wealthy visitors.

Hermanus, then, presents a stark choice to those who live with hunger: social abnegation or ongoing exploitation. Saluni's brief non-career as a recording artist highlights the consequences of this system for the imaginative lives of those who, unlike the Whale Caller, wish to achieve recognition within the broader culture. Saluni is hopeful after a radio man from Cape Town promises a recording deal featuring her and two young girls known as the Bored Twins. The Twins' mother, however, fears that the recorder will "steal" the Twins" voices (231). Her fear is not irrational: the novel has suggested that the chances the Twins will enjoy economic or social recognition through their art are slim to none. More likely, their voices will be "stolen" in the sense that they will be exploited by an entertainment industry that, like the service, fishing, and whale watching industries, are geared toward the tastes of the elite.

The mother's wisdom connects with her own experience as a worker within the tourist economy. Although she and the Twins' father work at the vineyards that produce wine for the wealthy, they must also "collect bones and scrap metal", for "there is no rest for the hungry" (228). When one of the Twins falls ill, they face the choice of nursing the child or dying of starvation (131). Exigent conditions do not forestall creativity and talent in the Bored Twins, but they certainly delimit the potential for facilitating expression outside of economies of exploitation and spectacle. Given such strictures, it is no wonder that the Twins, who are left of necessity at home alone by their parents during the day, 
are capital-B Bored. Diners in Hermanus's restaurants find that "the world is at peace with itself [...] They are at peace with the world" (107). Mda's novel allows for no such peace. The world he depicts is one in which luxury meals are obscene spectacles premised on the exploitation of those who claim a rightful share, such as Saluni, and the marginalization of those who accept what has been deemed a rightful share, such as the Whale Caller. It is a world in which the resulting hunger, both physical and creative, must be abhorred as a violent crime.

\section{Conclusion}

Mda's apartheid and postapartheid novels suggest that a just politics of the rightful share must consider how differently gendered relationships of dependency affect differently gendered aspirations to ownership of South Africa's abundant resources. Unlike Toloki, Bhonco, and the Whale Caller, Mda's women who live in poverty are not often granted the option of abstaining from unpaid social and economic responsibilities - even Saluni finds herself fatefully working as a de facto babysitter. Any calculation of their rightful share, the fiction reminds us, must reflect these additional responsibilities. At the same time, Mda also advocates addressing the inequitable distribution of responsibility regarding who is assumed as responsible for responding to the rightful claims of whom. For such assumptions, he makes clear, are also certainly gendered, as well as racialized and classed. In The Heart of Redness, Heitsi feels obligated to men but not to his mother, even as Camagu acknowledges his dependency on American tourists but not cooperative workers' dependency on him or vice versa. The predominantly white tourists in The Whale Caller attribute legitimacy only to the claims of their own pleasure, but the direct distributive claims of those whose exploitation ensures that pleasure are surely rightful, and surely the tourists' responsibility. While Mda's fictions of hunger affirm through their representation of food their own status as eccentric aesthetic objects, circulating in a patriarchal and exploitative global culture that caters to the tastes of the elite, they also struggle to reconstitute the terms of their own desirability: as luxuries rightfully available to all and as necessities that defy circumscriptions of responsibility.

\section{Acknowledgement}

I am grateful for research support from Oklahoma State University's College of Arts and Sciences Dean's Incentive Grant. An early version of this paper was presented at the 2015 Conference of the Canadian Association for Commonwealth Literature and Language Studies. I thank Alice Brittan for recommending Ferguson's work to me at that conference. Thanks also to the reviewers and editors at $J C L$ for suggestions that improved this essay.

\section{Declaration of Conflicting Interests}

The author(s) declared no potential conflicts of interest with respect to the research, authorship, and/or publication of this article.

\section{Funding}

The author(s) received no financial support for the research, authorship, and/or publication of this article. 


\section{Notes}

1. Multiple postapartheid novels by Mda are not addressed in this essay. The Madonna of Excelsior (2002) and Black Diamond (2009/2014) do not engage as directly with apartheid and postapartheid food security policies as my chosen texts. Cion (2007) features Toloki, but its treatment of hunger focuses on food insecurity in the US, a full discussion of which is beyond the scope of this paper. Rachel's Blue (2014) is also set in the US, while The Sculptors of Mapungubwe (2013) does not have a contemporary setting.

2. All subsequent references are to this edition of Ways of Dying and will be cited parenthetically by page number in the text.

3. See, for example, Barnard (2007), Kissack and Titlestad (2009), and Sewlell (2007).

4. Offenburger (2008: 164) finds "an abuse of textual borrowings" in The Heart of Redness. Mda's (2008) response to the article appears in the same journal issue.

5. I follow Samuelson (2009) in avoiding the oft-used nomenclature of "the Xhosa Cattle Killing Movement" to describe these events. As Samuelson demonstrates, the term minimizes the important role of women's labour at cultivation, as well as the devastating effects of its cessation.

6. All subsequent references are to this edition of The Heart of Redness and will be cited parenthetically by page number in the text.

7. Battersby's argument as to the marginalization of informal food sources focuses especially on current approaches to food insecurity in urban centres. The Heart of Redness suggests that, in developing policies targeted at rural areas, more attention could similarly be paid to "how people actually navigate their foodscapes" (Battersby, 2012: 155).

8. For a reading of the novel that argues that Mda perpetuates the appropriation and marginalization of feminized voices, see Meg Samuelson. She argues that Mda's novel "shows no interest in reading Nongqawuse as one engaged in 'postmodern' acts of decentering that grant authority to the female self through a cunning act of displacement", namely through "Nongqawuse's assumption of the [male] ancestral voice" (2009: 248). I argue that Mda's novel seeks to replicate this decentring, albeit by feminizing the masculine authorial voice.

9. All subsequent references are to this edition of The Whale Caller and will be cited parenthetically by page number in the text.

\section{References}

Barnard R (2007) Apartheid and Beyond: South African Writers and the Politics of Place. New York: Oxford University Press.

Battersby J (2012) Beyond the food desert: Finding ways to speak about urban food security in South Africa. Geografiska Annaler: Series B, Human Geography 94(2): 141-159.

Department of Agriculture, Forestry and Fisheries (2014) National policy on food and national security for the republic of South Africa. Government Gazette, 22 August.

Ferguson J (2015) Give a Man a Fish: Reflections on the New Politics of Distribution. Durham, NC: Duke University Press.

Goyal Y (2011) The pull of the ancestors: Slavery, apartheid and memory in Zakes Mda's Ways of Dying and Cion. Research in African Literatures 42(2): 147-169.

Isaacs M (2011) Individual transferable quotas, poverty alleviation, and challenges for small-country fisheries policies in South Africa. MAST 10(2): 26-84.

Jacobs PT (2011) Agro-food market policy and food security in South Africa. Development in Practice 21(4-5): 642-651.

Kepe T and Tessaro D (2014) Trading-off: Rural food security and land rights in South Africa. Land Use Policy 36: 267-274. 
Kissack M and Titlestad M (2009) Invidious interpreters: The post-colonial intellectual in The Heart of Redness. In: Bell D and Jacobs J (eds) Ways of Writing: Critical Essays on Zakes Mda. Pietermaritzburg: University of KwaZulu-Natal Press, 149-167.

Makhulu A (2012) The conditions for after work: Financialization and informalization in posttransition South Africa. PMLA 127(4): 782-799.

Mather C (2007) Sustainability and fisheries reform in post-apartheid South Africa. Geography 92(3): 221-230.

Mda Z (1991/1995) Ways of Dying. New York: Picador.

Mda Z (2000) The Heart of Redness. New York: Picador.

Mda Z (2002) The Madonna of Excelsior. New York: Picador.

Mda Z (2005) The Whale Caller. Johannesburg: Penguin.

Mda Z (2007) Cion. New York: Picador.

Mda Z (2008) A response to "Duplicity and plagiarism in Zakes Mda's The Heart of Redness" by Andrew Offenburger. Research in African Literatures 39(3): 200-203.

Mda Z (2009/2014) Black Diamond. London: Seagull Books.

Mda Z (2013) The Sculptors of Mapungubwe. London: Seagull Books.

Mda Z (2014) Rachel's Blue. Cape Town: Kwela Books.

Offenburger A (2008) Duplicity and plagiarism in Zakes Mda's The Heart of Redness. Research in African Literatures 39(3): 164-199.

Oliveira Gonçalves Pires AL (2013) From neglected history to tourist attraction: Reordering the past in Zakes Mda's The Heart of Redness. ARIEL: A Review of International English Literature 44(1): 127-151.

Peires JB (1989) The Dead Will Arise: Nongqawuse and the Great Xhosa Cattle-Killing Movement of 1856-57. Bloomington: Indiana University Press.

Salo K (2007) Contesting liberal legality: Informal legal cultures in post-apartheid South Africa's privatizing seafood industry. African Studies Quarterly 9(4): 107-125.

Samuelson M (2009) Nongqawuse, historical time and female authorship in Zakes Mda's The Heart of Redness. In: Bell D and Jacobs J (eds) Ways of Writing: Zakes Mda. Pietermaritzburg: University of KwaZulu-Natal Press, 229-253.

Sewlell H (2007) "Portmanteau biota" and ecofeminist interventions in Zakes Mda's Heart of Redness. JLS/TLW 23(4): 374-389.

Weale D and McLea P (2001) Love and Green Onions (Director \& Librettist, Williams M). Cape Town: Cape Town Opera. 